DOI: https://doi.org/10.15688/ek.jvolsu.2019.3.14

UDC 338:504.123(470+571)

Submitted: 10.07.2019

LBC 65.9(2)281

Accepted: 01.08.2019

\title{
ECOLOGICAL AND ECONOMIC ASPECTS OF LAND DESERTIFICATION
}

\author{
Alexander S. Rulev \\ Volgograd State University, Volgograd, Russian Federation
}

Gleb A. Rulev

Federal Research Center for Agroecology, Integrated Land Reclamation and Protective Afforestation of the Russian Academy of Sciences, Volgograd, Russian Federation

\begin{abstract}
Agricultural lands of the Russian Federation are intensively subjected to degradation and desertification as a result of irrational economic activity, which, against the background of unfavorable climatic factors, led to the destruction of natural ecosystems, degradation of the soil cover and ultimately to the creation of the unfavorable ecological environment. About $65 \%$ of 130 million hectares of arable land, are exposed to water and wind erosion. Only by water erosion, $10 \%$ of arable land lost $30-60 \%$ of fertility and almost $25 \%$ lost $10-30 \%$. As a result of deflation 25 million hectares of agricultural land in the European part of the Russian Federation are degraded to varying degrees. The concept of the anti-degradation arrangement proposes to use environmental-economic geoinformational monitoring. Within the framework of this approach, the development of cartographic and mathematical models in three time environments is proposed: pre-agricultural, modern degraded, and certainly improved condition. The ecological and economic analysis makes it possible to synthesize information flows and analyze the most important degradation processes. The most important tool for implementing ther adaptive-landscape anti-degradation arrangement of agricultural landscapes is precision farming, which consists of several subsystems: decision-making, monitoring, agronomic techniques, specialized equipment, etc. Computer technologies and telecommunications allow to speed up and optimize production by combining technology and people, which helps reduce costs. Precision agriculture is impossible without using modern advances in collecting, processing and storage of various, often heterogeneous, agricultural information.

Key words: desertification, land degradation, dust storm, GIS technology, adaptive-landscape design, precision agriculture.
\end{abstract}

Citation. Rulev A.S., Rulev G.A. Ecological and Economic Aspects of Land Desertification. Journal of Volgograd State University. Economics, 2019, vol. 21, no. 3, pp. 158-169. (in Russian). DOI: https://doi.org/10.15688/ ek.jvolsu.2019.3.14

УДК 338:504.123(470+571)

Дата поступления статьи: 10.07.2019

ББК 65.9(2)281

Дата принятия статьи: 01.08.2019

\section{ЭКОЛОГО-ЭКОНОМИЧЕСКИЕ АСПЕКТЫ ОПУСТЫНИВАНИЯ ЗЕМЕЛЬ}

\section{Александр Сергеевич Рулев}

Волгоградский государственный университет, г. Волгоград, Российская Федерация

\section{Глеб Александрович Рулев}

Федеральный научный центр агроэкологии, комплексных мелиораций и защитного лесоразведения РАН, г. Волгоград, Российская Федерация 
Аннотация. Сельскохозяйственные земли Российской Федерации интенсивно подвергаются деградации и опустыниванию в результате нерациональной хозяйственной деятельности, которая на фоне неблагоприятных природно-климатических факторов привела к разрушению природных экосистем, деградации почвенного покрова и в конечном итоге к созданию неблагоприятной экологической среды. Из 130 млн га пашни около 65 \% подвержены водной и ветровой эрозии. Только за счет водной эрозии $10 \%$ пашни потеряло 30-60 \% плодородия и почти 25 \% пашни - 10-30\%. В результате дефляции в европейкой части РФ деградировано в разной степени 25 млн га сельскохозяйственных земель. Концепция противодеградационного обустройства предлагает применение эколого-экономического геоинформационного мониторинга. В рамках этого подхода предлагается разработка картографо-математических моделей в трех временных срезах: доземледельческих, современных деградированных и безусловно улучшенного состояния. Эколого-экономический анализ делает возможным синтез информационных потоков, позволяет проанализировать наиболее важные деградационные процессы. Использование современных компьютерных программ для выполнения анализа позволяет обобщить информацию, привести необходимые экономические расчеты и разработать проекты противодеградационных мероприятий. Важнейшим инструментом реализации адаптивно-ландшафтного противодеградационного обустройства агроландшафтов является точное земледелие, состоящее из нескольких подсистем: принятия решений, мониторинга, агротехнических приемов, специализированной техники и др. Компьютерные технологии и телекоммуникации позволяют ускорить и оптимизировать производство за счет объединения техники и людей, что способствует сокращению затрат. Точное земледелие невозможно без использования современных достижений в сфере сбора, обработки и хранения различной, зачастую разнородной сельскохозяйственной информации.

Ключевые слова: опустынивание, деградация земель, пыльная буря, ГИС-технологии, адаптивно-ландшафтное обустройство, точное земледелие.

Цитирование. Рулев А. С., Рулев Г. А. Эколого-экономические аспекты опустынивания земель // Вестник Волгоградского государственного университета. Экономика. - 2019. - Т. 21, № 3. - С. 158-169. - DOI: https:// doi.org/10.15688/ek.jvolsu.2019.3.14

\section{Введение}

В Конвенции ООН по борьбе с опустыниванием явление опустынивания определяется как «деградация земель в аридных, субаридных и засушливых субгумидных районах в результате действия различных факторов, включая изменение климата и деятельность человека» [Конвенция ООН ... , 1996]. По данным ООН, на засушливые районы приходится до 43 \% возделываемых земель в мире. Деградация земель приводит к потерям на сумму примерно в 42 млрд долл. США в год [Золотокрылин и др., 2011].

В XX в. за счет резкого увеличения антропогенной нагрузки на биосферу произошло глобальное ухудшение экологической ситуации, что привело к аридизации и опустыниванию территорий, деградации и разрушению почв, изменению климата, способности агроэкосистем к саморегуляции и естественному восстановлению плодородия почв. В настоящее время 2/3пашни, 1/5 часть сенокосов и 1/2 площади пастбищ России подвержены разрушающему действию водной эрозии, дефляции, периодических засух, суховеев и пыль- ных бурь [Проблемы деградации ..., 2008]. Негативная агроэкологическая обстановка усугубляется высокой степенью распаханности и малой лесистостью сельскохозяйственных земель.

Характерной особенностью климата Волгоградской области в силу территориального расположения является его засушливость, которая возрастает с северо-запада на юго-восток, а также малоснежная зима с неустойчивым температурным режимом. За период вегетации выпадает всего 110-140 мм осадков, а испарение превышает их количество в 1,52,0 раза. Часто повторяющиеся засухи, наносящие сельскому хозяйству Волгоградской области колоссальный материальный ущерб, являются главной причиной крайне неустойчивого характера земледелия [Сажин и др., 2017]. По данным государственного земельного учета на 01.01.2016, земельный фонд Волгоградской области составляет 11 287,0 тыс. га. Большая часть территории Волгоградской области (около 80 \%) представлена землями сельскохозяйственного назначения [Итоги ... , 2018].

В последние годы сельскохозяйственные угодья занимают лишь 51 \% от общей терри- 


\section{ЭкоЛОГИя}

тории Волгоградской области, отмечается устойчивая тенденция сокращения продуктивных площадей. К настоящему времени территория пашни уменьшается, а растет площадь залежных земель. Почти в 2 раза (на 2139 га) за последнее десятилетие увеличилась территория залежи. Также существенно изменилась площадь под пастбищами: она возросла на 7,6 \%, то есть на 662,6 тыс. га.

\section{Материалы и методы исследования}

Применение интеллектуальных компьютерных технологий позволяет говорить о новой ситуации в исследованиях процессов деградации земель, тем более что в земледельческой науке право на существование получили новые направления - «точное земледелие» и «координатное земледелие», имеющие определенные различия. Одно из наиболее удачных определений сформулировано следующим образом: «Точное земледелие - такой тип сельскохозяйственного производства, при котором увеличивается количество правильных решений на единицу площади земли за единицу времени с соответствующим экологическим эффектом» [Якушев, 2015, с. 96].

В рамках направления возникает вопрос: имеет ли право на существование точная лесомелиорация агроландшафтов? Безусловно, имеет, так как она является подсистемой точного земледелия и как самостоятельное направление, и на землях несельскохозяйственного назначения.

За последние годы получили развитие системы дистанционного зондирования, значительно улучшились характеристики систем оптической съемки, стала доступной регулярная цифровая съемка высокого разрешения, применение космоснимков с пространственным разрешением до 5-10 метров для решения эколого-экономических задач. В настоящее время накоплены значительные массивы данных, которые доступны в сети Интернет. Например, архивные снимки систем Landsat-7 на сайте Google доступны для всей территории России.

Наличие космоснимков высокого разрешения, необходимое программное обеспечение, внедрение системы GPS для прецизионной привязки координат обеспечили возмож- ность координатной лесомелиорации. Концепция лесомелиоративного обустройства предполагает использование методологии экологоэкомического мониторинга деградированных земель. В рамках этого подхода предполагается составление картографическо-математических моделей в трех временных срезах: доземледельческих, современных деградированных и безусловно улучшенного состояния.

Эколого-экономический геоинформационный мониторинг агроландшафтов включает:

- сопряженный анализ и диагностику современного состояния агроландшафтов на основании интеллектуальных компьютерных технологий;

- изучение структуры и состава природно-антропогенных агроландшафтных структур;

- разработку эколого-экономических критериев оценки антропогенной деградации агроландшафтов;

- проведение эколого-экономического районирования;

- эколого-экономическое обоснование противодеградационных технологий.

\section{Методика}

В целом методология координатной лесомелиорации предполагает: камеральное дешифрирование среднемасштабных космических снимков агроландшафтов при разрешении до 30 м; полевое дешифрирование крупномасштабных космических снимков агроландшафтных объектов при разрешении до 10 м; полевое дешифрирование аэрокосмических снимков высокого разрешения до 3 м.

Эколого-экономический анализ делает возможным синтез информационных потоков, позволяет проанализировать наиболее важные деградационные процессы, установить тенденцию развития и сделать прогноз будущих состояний агроландшафтов. Использование современных компьютерных программ для выполнения анализа позволяет обобщить информацию, провести необходимые экономические расчеты, разработать проекты противодеградационных мероприятий. Экологоэкономический геоинформационный анализ антропогенно-трансформированных ландшафтов включает использование результатов космической съемки и геоинформационного 
анализа территорий для оценки состояния территорий и составления карт пространственного разделения деградации. При этом эффективность метода позволяет в 4 раза уменьшить время работы, а затраты сократить в 15 раз по сравнению с полевыми методами [Рулев, 2007].

Методика геоинформационного исследования состояния антропогенно-трансформированных ландшафтов основывается на ландшафтном подходе к исследованию территорий, учитывающем все главные компоненты, такие как рельеф, мезоклимат, почвы и гидрологические условия. Геоинформационное картографирование состояния территорий проводится при послойной оценке результатов дешифрирования их состояния. Сравнение разновременных картографических слоев позволяет выявить тенденцию изменения площади деградации по времени, подобрать математическую функцию и определить коэффициенты аппроксимации. Полученные уравнения дают возможность составить на математической основе прогнозные карты и в режиме моделирования определить состояние агроландшафтов с прогнозом деградации 5-10 лет. Цифровой геоинформационный слой - это, по сути, модель ландшафта, а пространственная информация дает возможность пользователю определять количественные характеристики объектов исследований.

Концепция точного земледелия необходима для разработки новых ресурсосберегающих технологий в растениеводстве, призванных увеличить производительность труда, повысить управляемость агропроизводства, найти выгодные в экономическом отношении культуры сорта, обеспечить рациональное использование земельных ресурсов и сократить издержки за счет оптимизации использования производственных ресурсов. Это невозможно без комплексного использования современных информационных технологий и глобальных систем спутниковой навигации.

Практика применения ГИС-технологий в точном земледелии позволяет классифицировать задачи, решаемые в среде ГИС, следующим образом:

- информационно-справочные задачи;

- пространственный анализ;
- моделирование (интеграция ГИС и моделей для определения показателей агротехнологий на единицах управления);

- анализ и принятие решений (анализ в среде ГИС эффективности различных агротехнологий) [Рулев и др., 2018].

На основе дешифрирования спутниковых снимков высокого разрешения была составлена карта структуры землепользования тестового полигона, определены границы полей. Геоинформационная обработка осуществлялась в программе QGIS 2.14. В атрибутивную информацию картографического слоя с границами полей внесены данные о структуре посевных площадей. На основе цифровой модели местности SRTM3 в результате морфологического анализа определены величины углов наклонов и экспозиций склонов. С помощью инструментов пространственного анализа и зональной статистики для контуров полей определены величины средних углов наклонов и преобладающей экспозиции, определены уровни деградации почв на полях.

Наполнение атрибутивных данных сведениями о структуре посевов, урожайности, агротехнических приемах за разные годы позволит получить базу, которая будет являться инструментом эффективного управления сельскохозяйственным производством. Для исследования углов наклона склонов в среде ГИС построен соответствующий растровый слой, иллюстрирующий пространственное положение участков ландшафта с различными величинами углов наклона склонов.

\section{Результаты и обсуждение}

Сельскохозяйственные земли Российской Федерации интенсивно подвергаются деградации и опустыниванию в результате нерациональной хозяйственной деятельности, которая на фоне неблагоприятных природно-климатических факторов привела к разрушению природных экосистем, деградации почвенного покрова и в конечном итоге к созданию неблагоприятной экологической среды для жизни людей. Из 130 млн га пашни около 65 \% подвержены водной и ветровой эрозии. Только за счет водной эрозии $10 \%$ пашни потеряло 30-60 \% плодородия и почти $25 \%$ пашни $10-30 \%$. В результате дефляции в европей- 
кой части РФ деградировано в разной степени 25 млн га сельскохозяйственных земель. Вынос почвенного субстрата ежегодно составляет 25 млн т, а потери гумуса достигают 750 тыс. т, которые практически не восполняются [Проблемы деградации ..., 2008].

Площадь действующих оврагов в России уже превышает 900 тыс. га. Ежегодный вынос пыли в атмосферу за счет дефляции составляет сегодня 0,37 т/га. Из 8,7 млн га сельскохозяйственных угодий Волгоградской области 2,2 млн га подвержено водной эрозии, из них 1,3 млн га пашни [Сажин и др., 2017]. По данным ФНЦ агроэкологии РАН, эффективность противоэрозионных защитных лесных насаждений (далее - ЗЛН) высокая и выражается в лучшем снегосохранении, сокращении поверхностного стока, его очистке, снижении смыва почвы, повышения урожая сельскохозяйственных культур [Агролесомелиорация, 2006].

Лесные полосы на склонах хорошо очищают сток от биогенных веществ, лесная полоса шириной 15 м способна снизить содержание в стоке нитратов и нитритов в 1,62,2 раза, калия - в 2 раза, пестицидов - в 22,5 раза [Агролесомелиорация, 2006]. Системы лесных насаждений на склонах, преобразуя водный и тепловой режим, интенсифицируют почвообразовательный процесс.

Пыльные бури на юге Российской Федерации периодически наносят серьезный ущерб сельскому хозяйству за счет выдувания верхнего и наиболее плодородного слоя почвы, тем самым существенно снижая урожай сельскохозяйственных культур. Наиболее сильные и разрушительные бури бывают в конце зимы и в ранневесенний период, когда над юго-восточной европейской территории России и Западным Казахстаном устанавливает обширный малоподвижный антициклон, который сохраняет свое влияние в течение нескольких синоптических периодов (в иные годы до 1,01,5 месяцев) [Васильев, 2003; Рулев и др., 2016; Сажин и др., 2017].

Важно отметить усиление дефляционных процессов за счет хозяйственной деятельности человека. В Волгоградской области ветроэрозионный потенциал агроландшафтов в среднем составляет 1,0-10 т/га, но есть участки с выносом 12-14, 22-25 и даже до 60-
70 т/га на сильно облегченных почвах и песках. В 2015 г. с 27 по 31 марта на территории Волгоградской области наблюдались сильные ураганные ветры до 22-24 м/с, максимальное проявление ветра приходилось на 2830 марта. В этот период верхний слой почвы 5-7 см (в отдельных местах до 9-11 см) изза высоких температур, нехарактерных для марта, и сухого воздуха был высушен как на юге, так и на севере области, а также на прилегающих территориях Калмыкии, Астраханской области и восточной части Ростовской области.

Пыльная буря с переносом почвы наблюдалась в зоне каштановых почв в Суровикинском, Чернышковском, Серафимовичском, Клетском, Фроловском, Ольховском, Котовском, Камышинском, Иловлинском районах. На севере области в зоне черноземных почв ветровая дефляция наблюдалась в Новониколаевском, Новоаннинском, Киквидзенском, Еланском, Жирновском районах, но особо сильно пострадали хозяйства вдоль русла реки Бузулук (х. Большевик). Огромное влияние на перенос оказало расстояние между лесными полосами, которое на исследуемых объектах превышает 1 км, для южных черноземов межполосное расстояние не должно превышать 600 м [Рулев и др., 2016].

Результаты почвенного анализа (см. таблицу) показали, что в насосах мелкозема содержится большое количество гумуса. В почвенных образцах, отобранных на территории Еланского района, содержание гумуса варьировалось от 2 до 3,5 \%, в образцах из Котельниковского района - до 1,6\%.

Таким образом, в 2015 г. пыльная буря 27-31 марта в Волгоградской области проявила себя в очень интенсивном режиме на площади 78 тыс. га, при средней интенсивности на площади 106 тыс. га и слабой интенсивности на площади 149 тыс. га с суммарной площадью 330 тыс. га.

Снижение продуктивности зерновых культур составило 1,2 т/га, что предопределило недополучение продукции на 5,7 млрд руб. и падение плодородия почвы за счет дефляции на сумму 18,0 млрд рублей. В итоге суммарный ущерб составил 24,5 млрд руб. [Рулев и др., 2016]. В связи с этим защита почвы от дефляции должна носить комплексный ха- 
Комплексный анализ почвенных образцов (наносы)

\begin{tabular}{|c|c|c|c|c|c|c|c|c|c|}
\hline \multirow[b]{2}{*}{$\begin{array}{l}\text { Место отбора } \\
\text { образца }\end{array}$} & \multicolumn{6}{|c|}{ Размеры фракции, мм } & \multirow[b]{2}{*}{$\begin{array}{c}\text { Физ. } \\
\text { глина, \% }\end{array}$} & \multirow[b]{2}{*}{$\begin{array}{l}\text { Содержание } \\
\text { углерода, \% }\end{array}$} & \multirow[b]{2}{*}{$\begin{array}{c}\text { Содержание } \\
\text { гумуса, \% }\end{array}$} \\
\hline & $1-0,25$ & $\begin{array}{c}0,25- \\
0,05\end{array}$ & $\begin{array}{c}0,05- \\
0,01\end{array}$ & $\begin{array}{l}0,01- \\
0,005\end{array}$ & $\begin{array}{c}0,005- \\
0,001\end{array}$ & $<0,001$ & & & \\
\hline Еланский район & 0,28 & 27,48 & 0,6 & 16,6 & 38,3 & 16,74 & 71,64 & 1,89 & 3,42 \\
\hline $\begin{array}{l}\text { Котельниковский } \\
\text { район }\end{array}$ & 1,04 & 9,06 & 31,06 & 12,31 & 19,31 & 27,22 & 58,84 & 0,85 & 1,60 \\
\hline
\end{tabular}

Примечание. Составлено авторами.

рактер и включать в себя систему организационно-хозяйственных, агротехнических и лесомелиоративных мероприятий. Наиболее эффективным способом предотвращения развития ветроэрозионного процессов являются защитные насаждения, которые, увеличивая общую шероховатость подстилающей поверхности, меняют структуру и снижают скорость ветра.

Антропогенно-трансформированные пастбищные комплексы на юго-востоке европейской России расположены на Сарпинской и Прикаспийской низменностях. Ландшафтные комплексы здесь формировались на молодой морской равнине, что обусловило небольшую мощность и гумусированность почв. Большую часть территории занимают малогумусированные пески с открытыми очагами дефляции, что в условиях полупустынного засушливого климата и большой площади засоления почв, податливости ветровой и водной эрозии способствует проявлению деградации и опустынивания, в первую очередь при неадекватном антропогенном воздействии на ландшафты [Кулик и др., 2012].

Территория Калмыкии, Волгоградской и Астраханской областей является примером последствий антропогенной трансформации, в результате которой были разрушены устойчивые полупустынные ландшафтные комплексы. В Республике Калмыкия в 2018 г. 34 \% земель имело проективное покрытие менее $10 \%$, в Астраханской области - $29 \%$. В связи с этим комплексная геоинформационная оценка деградации на основе данных спектрозональных космоснимков становится приоритетной в определении пространственного распределения и площади участков, подверженных деградации и опустыниванию. Преимуществом дистанционных методов является экономическая эффективность, обусловленная снижением затрат на выполнение оценки состояния ландшафтов. В последнее десятилетие на территории области наблюдается рост поголовья овец и коз в среднем на 30 тыс. голов в год, которое приближается к 1 млн голов [Дистанционные исследования ..., 2019]. Максимальные пастбищные нагрузки отмечаются в районах Заволжья, особенно в Николаевском и Палласовском, на правобережной территории лидирует Октябрьский район, но в большей части области пастбищные земли используются недостаточно, как и десять лет назад [Шинкаренко и др., 2016; Can Vegetation ..., 2013; Kulik, 2015].

Таким образом, одновременно имеются сильносбитые и практически неиспользуемые пастбища, для анализа состояния которых необходимо их пространственное разделение. Очевидно, что площадь реально используемых пастбищ значительно меньше, чем та, что приводится в статистических материалах, при этом в качестве пастбищ используются и старовозрастные залежи, площади которых могут относиться к пашням. Соответственно, необходим более адекватный подсчет площадей эксплуатируемых пастбищных и сенокосных земель и пересчет нагрузок на них. Подобный пространственный анализ возможен только на основе данных дистанционного зондирования.

В России с 1990 г. выбыло из сельскохозяйственного оборота 25,6 млн га сельхозугодий, в том числе 8,2 млн га пашни. Урожай сельскохозяйственных культур на деградированных землях снижается на $10-80$ \% в зависимости от степени деградации. В результате недобор земледельческой продукции в пересчете на зерно составляет примерно 47 млн т [Проблемы деградации ..., 2008].

В арсенале средств борьбы с деградацией земель и повышения их плодородия нет более мощного средства, чем защитные лесные насаждения (далее - ЗЛН). Они являют- 


\section{ЭкоЛОГИя}

ся одним из наиболее эффективных, долговечных и устойчивых компонентов почвозащитного комплекса. Защитные лесные насаждения являются экологической инфраструктурой агроландшафтов. Обладая ярко выраженными ландшафтно-стабилизирующими свойствами, они служат экологическим каркасом территории. При адаптивно-ландшафтном обустройстве территории России ЗЛН обеспечат полное предотвращение деградации и опустынивания, повышение влагообеспеченности, увеличение урожая сельскохозяйственных культур на 2-9 ц/га, повышение биоразнообразия и условий проживания людей.

В России около 3 млн га ЗЛН. Для полного адаптивно-ландшафтного обустройства 156 млн га сельскохозяйственных земель необходимо еще посадить 3 млн га. Собственниками этих насаждений является государство и частные сельхозтоваропроизводители. Государство передало ЗЛН и сельские леса в управление регионам, но фактически они оказались бесхозными.

Ключевым понятием адаптивно-ландшафтного (лесомелиоративного) обустройства является определение агролесоландшафта. В нашем понимании агролесоландшафт есть модификация агроландшафта, формирующегося и функционирующего под влиянием систем ЗЛН, обладающих стабилизирующим биогеофизическим воздействием на окружающее пространство, способствующих восстановлению деградирующих компонентов ландшафта, являющихся основой адаптивной организации агропроизводства и землепользования, а также сохраняющих биологическое разнообразие агротерриторий и направленных на улучшение социально-экономических условий жизни населения.

Стратегия сельского хозяйства должна быть ориентирована на новый этап - адаптивно-ландшафтное землепользование, базирующееся на принципиально новых точных (координатных) агролесомелиоративных технологиях, которые должны обеспечивать достижение высокой продуктивности агроландшафтов без нарушения экологического баланса территории.

Система точного земледелия основана на принятии стратегических решений на базе информационных технологий и различных источ- ников данных (сельскохозяйственное производство, финансы и т. д.). Потенциал точного сельского хозяйства заключается в управлении производством с учетом пространственно-временной изменчивости почвенного плодородия, природно-климатических условий и состояния растительности, а также в мониторинге этих и других показателей [A Technical ..., 2011; Quantifying vegetation ..., 2000; Remote Sensing ... , 2015]. В современных условиях функционирования агробизнеса в ведущих агропромышленных компаниях складывается тенденция необходимости внедрения современных информационных и технологических разработок.

Точное земледелие является интегрирующим комплексом технологий, состоящим из нескольких подсистем: принятия решений, мониторинга, агротехнологических приемов, специализированной техники и т. п. [Рулев и др., 2018; Якушев, 2008; Якушев, 2015]. Компьютерные технологии и телекоммуникации позволяют ускорить и оптимизировать производство за счет объединения техники и людей, что способствует сокращению затрат. Точное земледелие невозможно без использования современных достижений в сфере сбо$\mathrm{pa}$, обработки и хранения различной, зачастую разнородной сельскохозяйственной информации. При снижении стоимости и повышении доступности и оперативности получения данных дистанционного зондирования Земли, систем мобильной навигации, навигационной информации и устройств складываются все условия для развития сельского хозяйства как отдельных регионов, так и в масштабах страны.

Система точного земледелия:

- предусматривает создание и применение высокоточных ресурсосберегающих агротехнологий;

- обеспечивает качественный и количественный скачок в развитии сельского хозяйства для достижения конкурентоспособности на мировом рынке;

- базируется на новейших достижениях в области высоких технологий, прежде всего на использовании глобальной системы позиционирования, дистанционного зондирования земли, дешифрования тематической информации, прогнозирования на этой основе урожайности в привязке с высокой точностью к выбранной системе координат. 
Прогресс агропромышленного производства невозможно представить без высокоэффективной системы точного земледелия, включающей в том числе современные технологии сбора, обработки и хранении информации. Оптимальный инструмент для этих целей - геоинформационные технологии (ГИС), являющиеся основной подсистемой поддержки принятия технологических решений в точном земледелии. ГИС вместе с высокотехнологичными системами (системы спутниковой навигации, бортовые компьютеры, роботизированные машины и агрегаты) являются технологическим ядром в области точного земледелия.

Геоинформационные технологии для картографирования земель сельскохозяйственного назначения на сегодняшний день широко применяются в развитых странах, где являются стратегическим направлением аграрной политики. Это связано с тем, что электронные карты полей (угодий) как элементарные операционные единицы хранения информации являются основой любой информационной системы контроля производства.

Многие компоненты агрокомплекса постоянно модернизируются, вкладываются значительные финансовые ресурсы в закупку оборудования для точного земледелия и контроля работ тяжелой техники. Однако данные технологии становятся неэффективными при отсутствии точных электронных карт полей, позволяющих заранее планировать многочисленные операции (траектории движения техники, маршруты, их протяженность и продолжительность, постанализ работ), оперативно оценивать состояние агросистем, принимать современные управленческие решения [A Technical ..., 2011; Remote Sensing ..., 2015]. Также становится возможным анализ пространственных характеристик угодий - величин уклонов, экспозиции и т. п. Данные дистанционного зондирования могут быть использованы при составлении управляющих карт для проведения операций агроцикла, в том числе и для дифференцированного внесения минеральных удобрений, химических средств защиты растений и мелиорантов. Перспективно применение методов точного сельского хозяйства и для лесомелиоративного обустройства агроландшафтов.
Важнейшими инструментами предотвращения деградации земель сельскохозяйственного назначения являются агротехнологии точного земледелия и координатного агролесомелиоративного обустройства территории. Адаптивно-ландшафтное обустройство территории Волгоградской области и системы точного земледелия должны включать оценку почвенно-климатического потенциала. Особое значение имеет агроланшафтное районирование территории, которое является основой для адаптивно-ландшафтного обустройства территории.

Длительное время используемые системы земледелия основывались на физико-географическом, природно-сельскохозяйственном, почвенно-географическом районировании территории области. При физико-географическом районировании выделялись 2 зоны (степная и полупустынная), 8 провинций и 22 района, при природно-сельскохозяйственном и почвенно-географическом - 3 зоны (степная, сухостепная и полупустынная), 5 провинций и 7 природно-сельскохозяйственных районов.

Для планирования земледельческой деятельности и дифференцированного характера использования земель предложено агроландшафтное районирование Волгоградской области. Выделено три типологические группы [междуречные эрозионно-денудационные возвышенные и низменные равнины (Волго-Донское междуречье, правобережье Среднего Дона); древнеморские аккумулятивные низменны равнины (Прикаспийская низменность); песчаные и пойменные аккумулятивные равнины (речные долины Волги и Дона и их притоков)], 7 агроландшафтных районов (степной, равнинно-волнистый, черноземный; сухостепной, возвышенный, темно-каштановый и каштановый; пустынно-степной равнинно-волнистый, светло-каштановый; сухостепной, плоскоравнинный, солонцово-каштановый; пустынно-степной, плоскоравнинный, светло-каштановый; песчано-суглинистый, лесолуговые поймы; надпойменные песчаные террасы). В первой типологической группе земель (Волго-Донское междуречье и правобережье Среднего Дона) деградация происходит в основном в результате водной эрозии, и земледельческая деятельность здесь должна быть направлена на предотвращение эрозионных 
процессов. Во второй и третьей типологической группах земель протекают процессы дефляции, и земледелие здесь должно быть противодефляционным.

Типологические группы, в свою очередь, делятся на агроландшафтные районы, которые отличаются типами почв и рельефом. Дифференциация систем земледелия в них еще более выражена. Активное обустройство территории включает противоэрозионную, противодефляционную организацию территории на богаре, при орошении и на малопродуктивных землях аридной зоны, обустройство земель лесного фонда, пойм, особо охраняемых природных территорий (далее ООПТ), техногенно нарушенных земель, зон рекреации и др.

Для аридной зоны с малопродуктивными землями их организация предусматривает, в зависимости от степени аридности и деградации, создание агролесных, лесопастбищных, агролесопастбищных, многоотраслевых лесоаграрных, лесоплодовых, аквалесных, энтомолесных, рекреационно-лесохозяйственных, лесоохотничьих систем и ландшафтов с упором на фитомелиорацию с поверхностным и коренным улучшением пастбищ и размещением специальных систем ЗЛН, обеспечивающих повышение продуктивности земель аридной зоны путем борьбы с засухой, дефляцией и эрозией.

На землях лесного фонда, в поймах рек, при создании ООПТ, зон рекреации, выполнении рекультивационных работ планируется проведение главным образом фитомелиоративных мероприятий по сохранению и восстановлению естественного режима их функционирования и получению специфического природно-хозяйственного эффекта, обусловленного целевым назначением этих объектов.

Защитные лесные насаждения противоэрозионного назначения в регионе представлены стокорегулирующими лесными полосами, приовражными и прибалочными лесополосами, насаждениями в оврагах, балках, коренных берегах рек. Их общее количество в регионе составляет от потребности по стокорегулирующим лесополосам - 30-40 \%, приовражными и прибалочными - 75-80 \%, овражно-балочным насаждениям - 10-15\% [Агролесомелиорация, 2006]. Созданы они фрагментарно по водосбросам и не составляют единой системы ЗЛН.

Обеспечение системы мероприятий по адаптивно-ландшафтному обустройству территории без применения дистанционной информации (космоснимков высокого разрешения) невозможно. Экономическая эффективность применения дистанционной информации при изучении и оценке деградации земель и последующем электронном картографировании для обоснования и проектирования противодеградационных мероприятий, включая агролесомелиоративные и лесохозяйственные, складывается:

- из экономии средств от сокращения объемов полевых изысканий;

- сокращения числа исполнителей;

- сокращения времени составления проектов.

Определение экономической эффективности производится путем сравнения расчетных затрат на выполнение проективно-изыскательских работ наземными методами и с применением дистанционных материалов (космоснимков высокого разрешения) по средним показателям на 1000 га лесных полос.

Расчеты показали, что сумма расходов при выполнение работ на основе дистанционных методов в 1,3 раза меньше, чем при выполнении наземными методами. Экономический эффект от сокращения денежных затрат на обследование всех ЗЛН полигона и разработку рекомендаций по проведению лесохозяйственных мероприятий составит 1 млн рублей. Помимо этого, почти в 2 раза уменьшаются затраты по времени производства всех видов работ, и, соответственно, происходит сокращение численности исполнителей, что приводит к повышению точности и объективности получаемой информации.

\section{Заключение}

В Российской Федерации на базе Института географии РАН создан Научно-координационный центр по борьбе с опустыниванием и смягчению последствий засухи имени Н.Ф. Глазовского (НКЦ БОЗ). Сформирована межведомственная группа экспертов по проблеме «Глобальный климат и рациональное природопользование: нуль-эмиссия и нуль- 
деградация почв России (сельское и лесное хозяйство)».

Разрабатывается Национальный доклад «Земельные ресурсы России и проблемы опустынивания: глобальные вывозы, состояние и перспективы». Подготовка этого Национального доклада планируется в целях формирования гармонизированной платформы и объединения усилий экспертного сообщества при выработке механизмов управления рисками опустынивания, деградации земель и засух в Российской Федерации для устойчивого развития и выполнения международных обязательств России.

Доклад анализирует сценарии деградации земель в России по отдельным регионам и субъектам Федерации, представленные с использованием международных методических подходов, а также полученные в рамках секторальных и тематических оценок на национальном уровне. В нем приводится оценка финансовых и институциональных механизмов, направленных на решение проблем деградации земель и опустынивания в наиболее опасных регионах России, дается анализ перспектив земельного рынка в условиях земельной реформы и разных сценариев деградации или улучшения состояния земельных ресурсов.

Издание служит целям обоснования и подготовки Национальной стратегии и Плана действий по борьбе с опустыниванием и для достижения нейтрального баланса деградации земель. Эти стратегические документы предусмотрены обязательствами РФ по достижению Глобальных целей устойчивого развития на период до 2030 г. и по участию в Конвенции ООН по борьбе с опустыниванием. В разделе региональные проблемы опустынивания, деградации земель и засух Волгоградскую область представляют академики РАН К.Н. Кулик, А.С. Рулев.

\section{СПИСОК ЛИТЕРАТУРЫ}

Агролесомелиорация / под ред. А. Л. Иванова, К. Н. Кулика. - 5-е изд., перераб. и доп. - Волгоград : ВНИАЛМИ, 2006. - 746 с.

Васильев, Ю. И. Эффективность систем лесных полос в борьбе с дефляцией почв / Ю. И. Васильев. - Волгоград : ВНИАЛМИ , 2003. - 176 с.

Дистанционные исследования и картографирование состояния антропогенно-трансформиро- ванных территорий Юга России / В. В. Новочадов, А. С. Рулев, В. Г. Юрефев, Е. А. Иванцова // Известия Нижневолжского агроуниверситетского комплекса: наука и высшее профессиональное образование. - 2019. - № 1.C. 151-158.

Золотокрылин, А. Н. Новый подход к мониторингу очагов опустынивания / А. Н. Золотокрылин, Т. Б. Титкова // Аридные экосистемы. - 2011. Т. 17, № 3 (48). - С. 14-22.

Итоги Всероссийской сельскохозяйственной переписи 2016 г. по Волгоградской области. ТЗ: Земельные ресурсы и их использование. Волгоград : Волгоградстат, 2018. - 140 c.

Конвенция ООН по борьбе с опустыниванием в тех странах, которые испытывают серьезную засуху и/или опустынивание. - Женева : [б. и.], 1996. $-76 \mathrm{c}$.

Кулик, К. Н. Динамическая устойчивость аридных экосистем / К. Н. Кулик, А. Н. Салугин, Е. А. Сидорова // Аридные экосистемы. -2012. - Т. 18, №2 (51). - С. 29-35.

Проблемы деградации и восстановления продуктивности земель сельскохозяйственного назначения в России / под ред. А. В. Гордеева, Г. А. Романенко. - М. : Росинформагротех, 2008. $-67 \mathrm{c}$.

Рулев, А. С. Геоинформационные технологии в обеспечении точного земледелия / А. С. Рулев, С. С. Шинкаренко, В. Н. Бодрова // Известия Нижневолжского агроуниверситетского комплекса: наука и высшее профессиональное образование. - 2018. - № 4. - С. 115-122.

Рулев, А. С. Исследование проявления дефляции почв в условиях Волгоградской области / А. С. Рулев, А. М. Беляков, А. Н. Сарычев // Известия Нижневолжского агроуниверситетского комплекса: наука и высшее профессиональное образование. - 2016. - № 2 (42). C. 101-107.

Рулев, А. С. Ландшафтно-географический подход в агролесомелиорации / А. С. Рулев. - Волгоград : ВНИАЛМИ, 2007. - 106 с.

Сажин, А. Н. Погода и климат Волгоградской области / А. Н. Сажин, Ю. И. Васильев. - Волгоград : ФНЦ агроэкологии РАН, 2017. - 334 c.

Шинкаренко, С. С. Геоинформационное обеспечение противодефляционных мероприятий в муниципальных образованиях Волгоградской области / С. С.Шинкаренко, А. А. Пономарева // Формирование и развитие сельскохозяйственной наук в XXI веке (с. Соленое Займище, 25 июля 2016 г.) : сб. науч. ст. - Соленое Займище : [б. и.], 2016.- С. 94-101.

Якушев, В. П. Геоинформационное обеспечение прецизионных экспериментов в земледелии 
/ В. П. Якушев, А. В. Конев, В. В. Якушев // Геоинформатика. - 2015. - № 3. - С. 96-101.

Якушев, В. П. К проблеме агрофизических основ систем земледелия нового поколения / В. П. Якушев // Плодородие. - 2008. - № 6. - С. 22-24.

A Technical Opportunity Index Adapted to Zone-Specific Management / P. Roudier [et al.] // Precision Agriculture.-2011. - Vol. 12.-P. 130-145.

Can Vegetation Productivity Be Derived from Greenness in a Semi-Arid Environment? Evidence from Ground-Based Measurements / C. Mbow [et al.] // J. Arid Environments. 2013. - Vol. 97. - P. 56-65.

Kulik, K. N. Geoinformation Analysis of Desertification Dynamics in the Territory of Astrakhan Oblast / K. N. Kulik, A. S. Rulev, V. G. Yuferev // Aridnye Ekosistemy.-2015. - Vol. 21, №3 (64). - P. 25-35.

Quantifying Vegetation Change in Semiarid Environments: Precision and Accuracy of Spectral Mixture Analysis and the Normalized Difference Vegetation Index / A. Elmore [et al.] // Remote Sensing of Environment. - 2000. № 73. - P. 87-102.

Remote Sensing and GIS for Habitat Quality Monitoring: New Approaches and Future Research /A. Zlinszky [et al.] // Remote Sensing. - 2015. -№ 7 (6). - P. 7987-7994.

\section{REFERENCES}

Ivanov A.L., Kulik K.N., eds. Agrolesomelioratsiya [Land and Forest Reclamation]. Volgograd, VNIALMI Publ., 2006. 746 p.

Vasilyev Yu.I. Effektivnost sistem lesnykh polos v borbe $s$ deflyatsiey pochv [Effectiveness of Forest Belt Systems in Combating Soil Deflation]. Volgograd, VNIALMI Publ., 2003. 176 p.

Novochadov V.V., Rulev A.S., Yurefev V.G., Ivantsova E.A. Distantsionnye issledovaniya i kartografirovanie sostoyaniya antropogenno-transformirovannykh territoriy Yuga Rossii [Remote Research and Mapping of the State of Anthropogenically Transformed Territories of the South of Russia]. Izvestiya Nizhnevolzhskogo agrouniversitetskogo kompleksa: nauka i vysshee professionalnoe obrazovanie [Proceedings of Nizhnevolzskiy Agrouniversity Complex: Science and Higher Vocational Education], 2019, no. 1, pp. 151-158.

Zolotokrylin A.N., Titkova T.B. Novyy podkhod k monitoringu ochagov opustynivaniya [A New Approach to Monitoring Desertification Foci]. Aridnye ekosistemy [Arid Ecosystems], 2011, vol. 17, no. 3 (48), pp. 14-22.

Itogi Vserossiyskoy selskokhozyaystvennoy perepisi 2016 g. po Volgogradskoy oblasti.
TZ: Zemelnye resursy i ikh ispolzovanie [Results of the All-Russian Agricultural Census of 2016 in Volgograd Region. Land Resources and Their Use]. Volgograd, Volgogradstat, 2018. $140 \mathrm{p}$.

Konventsiya OON po borbe s opustynivaniem v tekh stranakh, kotorye ispytyvayut seryeznuyu zasukhu i/ili opustynivanie [United Nations Convention to Combat Desertification in Those Countries Experiencing Serious Drought and / or Desertification]. Geneva, 1996.76 p.

Kulik K.N., Salugin A.N., Sidorova E.A. Dinamicheskaya ustoychivost aridnykh ekosistem [Dynamic Stability of Arid Ecosystems]. Aridnye ekosistemy [Arid Ecosystems], 2012, vol. 18, no. 2 (51), pp. 29-35.

Gordeev A.V., Romanenko G.A., eds. Problemy degradatsii $i$ vosstanovleniya produktivnosti zemel selskokhozyaystvennogo naznacheniya $v$ Rossii [Problems of Degradation and Restoration of Agricultural Land Productivity in Russia]. Moscow, Rosinformagrotekh, 2008. 67 p.

Rulev A.S., Shinkarenko S.S., Bodrova V.N. Geoinformatsionnye tekhnologii v obespechenii tochnogo zemledeliya [Geoinformation Technologies in Ensuring Precision Farming]. Izvestiya Nizhnevolzhskogo agrouniversitetskogo kompleksa: nauka i vysshee professionalnoe obrazovanie, 2018, no. 4,pp. 115-122.

Rulev A.S., Belyakov A.M., Sarychev A.N. Issledovanie proyavleniya deflyatsii pochv $\mathrm{v}$ usloviyakh Volgogradskoy oblasti [Study of Soil Deflation in the Conditions of Volgograd Region]. Izvestiya Nizhnevolzhskogo agrouniversitetskogo kompleksa: nauka i vysshee professionalnoe obrazovanie, 2016, no. 2 (42), pp. 101-107.

Rulev A.S. Landshaftno-geograficheskiy podkhod v agrolesomelioratsii [Landscape-Geographical Approach in Agroforestry]. Volgograd,VNIALMI Publ., 2007. 106 p.

Sazhin A.N., Vasilyev Yu.I. Pogoda $i$ klimat Volgogradskoy oblasti [Weather and Climate of Volgograd Region]. Volgograd, FNTs agroekologii RAN, 2017. 334 p.

Shinkarenko S.S., Ponomareva A.A. Geoinformatsionnoe obespechenie protivodeflyatsionnykh meropriyatiy $\mathrm{v}$ munitsipalnykh obrazovaniyakh Volgogradskoy oblasti [Geoinformation Support of Anti-Deflationary Measures in the Municipalities of Volgograd Region]. Formirovanie $i$ razvitie selskokhozyaystvennoy nauk $v$ XXI veke (s. Solenoe Zaymishche, 25 iyulya 2016 g.) : sb. nauch. st. [Formation and Development of Agricultural Sciences in the $21^{\text {th }}$ Century (Solenoe Zaymishche, July 25, 2016). Collection of Scientific Articles]. 2016, pp. 94-101. 
Yakushev V.P., Konev A.V., Yakushev V.V. Geoinformatsionnoe obespechenie pretsizionnykh eksperimentov v zemledelii [Geoinformational Support of Precision Experiments in Agriculture]. Geoinformatika, 2015, no. 3,pp.96-101.

Yakushev V.P. K probleme agrofizicheskikh osnov sistem zemledeliya novogo pokoleniya [To the Problem of Agrophysical Foundations of Farming Systems of the New Generation]. Plodorodie, 2008, no. 6, pp. 22-24.

Roudier P., et al. A Technical Opportunity Index Adapted to Zone-Specific Management. Precision Agriculture, 2011, vol. 12, pp. 130-145.

Mbow C., et al. Can Vegetation Productivity Be Derived from Greenness in a Semi-Arid Environment?
Evidence from Ground-Based Measurements. Arid Environments, 2013, vol. 97, pp. 56-65.

Kulik K.N., Rulev A.S., Yuferev V.G. Geoinformation Analysis of Desertification Dynamics in the Territory of Astrakhan Oblast. Aridnye Ekosistemy, 2015, vol. 21, no. 3 (64), pp. 25-35.

Elmore A.J., et al. Quantifying Vegetation Change in Semiarid Environments: Precision and Accuracy of Spectral Mixture Analysis and the Normalized Difference Vegetation Index. Remote Sensing of Environment, 2000, no. 73, pp. 87-102.

Zlinszky A., et al. Remote Sensing and GIS for Habitat Quality Monitoring: New Approaches and Future Research. Remote Sensing, 2015, no. 7 (6), pp. 7987-7994.

\section{Information about the Authors}

Alexander S. Rulev, Doctor of Sciences (Agriculture), Academician of the Russian Academy of Sciences, Professor, Department of Geography and Cartography, Volgograd State University, Prosp. Universitetsky, 100, 400062 Volgograd, Russian Federation, rulev@volsu.ru, https://orcid.org/0000-0001-6152-288X

Gleb A. Rulev, Candidate of Sciences (Agriculture), Researcher, Laboratory of Agroecology and Prediction of Agro-Forest Landscapes Bioproductivity, Federal Research Center for Agroecology, Integrated Land Reclamation and Protective Afforestation of the Russian Academy of Sciences, Prosp. Universitetsky, 97, 400062 Volgograd, Russian Federation, g.heroes@yandex.ru, https://orcid.org/0000-0002-3815-0448

\section{Информация об авторах}

Александр Сергеевич Рулев, доктор сельскохозяйственных наук, академик РАН, профессор кафедры географии и картографии, Волгоградский государственный университет, просп. Университетский, 100, 400062 г. Волгоград, Российская Федерация, rulev@volsu.ru, https://orcid.org/0000-0001-6152-288X

Глеб Александрович Рулев, кандидат сельскохозяйственных наук, научный сотрудник лаборатории агроэкологии и прогнозирования биопродуктивности агролесоландшафтов, Федеральный научный центр агроэкологии, комплексных мелиораций и защитного лесоразведения РАН, просп. Университетский, 97, 400062 г. Волгоград, Российская Федерация, g.heroes@yandex.ru, https://orcid.org/0000-0002-3815-0448 